Stanislaw RESZKA, Żywot Księdza Stanislawa Hozjusza (Polaka), Kardynała Świętego Kościoła Rzymskiego, Penitencjarza Wielkiego i Biskupa Warmińskiego. Wstęp, przeklad z wydania w Oliwie 1690 r. i komentarze s. Jadwiga Ambrozja Kalinowska OSB, Olsztyn 2009, Warmińskie Wydawnictwo Diecezjalne, ss. 351.

Recenzowana książka zawiera: stronę tytułową polskiego przekładu, stronę tytułową pierwszego (1587 r.) wydania starego druku w języku łacińskim (stron 504 in octavo) i drugiego (1690 r.) - podstawy dokonanego przekładu, Wprowadzenie i Wstep do polskiego przekładu Vita D. Stanislai Hosii (s. 9-28), Summary i Sommario (s. 29-30), Wstęp do II edycji Vita D. S. Hosii, Olivae 1690 S. Bużeńskiego (s. 3336) oraz wstęp S. Reszki do I edycji D. Stanislai Hosii vita, Romae 1587 (s. 39-40). Kolejną częścią książki jest przekład Żywota księdza Stanisława Hozjusza zawarty $w$ trzech księgach (s. 43-248). Pierwsza księga liczy XXV rozdziałów, druga - XXXIV, trzecia - XX rozdziałów. Autorka znakomitego dzieła umieszcza także: Dodatek Stanisława Reszki, to jest: mowę, wygłoszoną przez Tomasza Tretera na pogrzebie ks. kardynała Hozjusza (s. 251-256) i 3 listy Reszki: do króla Stefana Batorego (s. 259-288), do ojca Rogera Gyrard (s. 291-292) oraz do Jana Kreczmera, kanclerza biskupa Marcina Kromera (s. 295-301). Wreszcie dodaje suplement, który zawiera wykaz skrótów (s. 303-305), bibliografię (s. 307-316) i indeksy (s. 317348): osobowy, nazw geograficznych i rzeczowy, cytatów biblijnych, cytatów patrystycznych, cytatów z dzieł antycznych autorów przedchrześcijańskich. Indeksy, które niewątpliwie bardzo ubogacają pracę i są bardzo istotne, mogą się stać bodźcem do dalszych rozpraw. Bardzo cenne są tak bardzo rozbudowane przypisy, że stanowią znakomity komentarz, podnoszą walor pracy, przybliżają osoby, wydarzenia, zapożyczenia i przytoczenia ze starożytnych autorów przedchrześcijańskich greckich i rzymskich, z pism pisarzy wczesnochrześcijańskich i Ojców Kościoła. Są to uwagi ważne i nieodzowne, wręcz konieczne.

We Wprowadzeniu (s. 9-10) do całości przekładu Autorka przedstawiła najistotniejsze rysy osoby i działalności księdza Stanisława kardynała Hozjusza i uzasadniła potrzebę polskiego przekładu jego biografii, napisanej przez naocznego kompetentnego świadka, dobrze do tej pracy przygotowanego, bo długoletniego jego sekretarza, księdza Stanisława Reszkę.

We Wstępie do polskiego przekładu (s. 13-26) Siostra Profesor słusznie zaprezentowała osobę Stanisława Reszki - autora Stanislai Hosii vita. Siostra Ambrozja Kalinowska dobrze ukazała literacką i kulturalną oraz dyplomatyczną działalność Reszki. Naświetliła genezę dzieła, przedstawiła wiarygodność przekazu, kompozycję utworu i wzorce literackie. Uwzględniła dotychczasowe wydania i dedykacje Życia Hozjusza, sporo uwagi poświęciła przekładowi niemieckiemu tego dzieła (wyd. w Ingolstadt w 1591 r.). Trafnie też dokonała wyboru II edycji $D$. S. Hosii vita (wyd. Olivae 1690) jako podstawę polskiego przekładu po skolacjonowaniu go z I edycją D. S. Hosii vita (Romae 1587) i jasno go uzasadniła.

Z radością zatem należy przyjąć owoc niemałego wysiłku Siostry Profesor. Przekład siostry J. A. Kalinowskiej może stać się natchnieniem i źródłem dla wie- 
lu nowych opracowań wielkiej postaci ks. Stanisława kardynała Hozjusza, jak i problemów jego czasów. Podjęcie tego tematu wymagało od Autorki niemałej odwagi, bo napisała dzieło, które będzie służyło wielu pokoleniom. Do tego potrzebna była nie tylko dobra znajomość języka łacińskiego i realiów tamtego okresu, ale także bibliografii. Jedna osoba zrobiła coś, nad czym powinien pracować zespół specjalistów różnych dziedzin. Posługując się słowami Horacego, wypowiedzianymi o własnym ojcu, można stwierdzić o siostrze J.A. Kalinowskiej: laus illi debetur et a me gratia maior $=$ „chwała jej się należy w ogóle, a ode mnie - jeszcze większa wdzięczność" (Sermones I 6, 68). Studium siostry profesor dr hab. J.A Kalinowskiej, wymagało dużo odwagi i wysiłku, bo trzeba było dokonać doboru i analizy źródeł, przekładu na język polski i objaśnienia wielu kwestii.

Siostra Profesor stoi jakby w opozycji do powszechnie znanego i nieraz przytaczanego przysłowia: Aliena nobis, nostra plus aliis placent $(=$ „Cudze bardziej nam się podoba, nasze innym” lub „Cudze chwalicie, swego nie znacie”. Siostrę Ambrozję słusznie zainteresowały nostra. Napisała dobre dzieło dla współczesnych i przyszłych pokoleń. W ten sposób jako filolog klasyczny stała się jakby imitatorem Auzoniusza, jego Commemoratio professorum Burdigalensium, a może i więcej, bo nie tylko upamiętnia i przybliża wierny portret uczonego i pasterza, myśliciela i biskupa, kardynała Hozjusza, ale także i przede wszystkim przekazuje przyszłym pokoleniom cenną jego doktrynę. Myślę, że tę pracę trzeba uznać za wyjątkowe osiągnięcie naukowe i wpisać w nurt testis veritatis.

Ks. Augustyn Eckmann - Lublin, KUL

\section{Miri RUBIN, Mother of God. A History of the Virgin Mary, New Haven - London 2009, Yale University Press, pp. 533.}

Miri Rubin jest profesorem historii w Queen Mary University w Londynie. Jej prezentowana książka dotyczy mediewistyki maryjnej pokazując różne indywidualno-społeczne formy kształtowania się obrazu N. M. P. w historii chrześcijaństwa, od jego początków aż do 1600 roku. Autorka chce w niej wyjaśnić, jak to się stało, że Maryja z prostej matki Jezusa, o której tylko Ewangelie nieśmiało wspominają, stała się globalną ikoną świata (s. XXVI). Kryterium rozważań stanowią okresy historyczne i pozostawione w nich miejsca oraz zabytki kultury materialno-duchowej związanej z postacią Maryi.

Cała książka została podzielona na sześć części, według poszczególnych okresów czasowych, które Autorka sama obrała. Całość jest poprzedzona spisem treści, ilustracji, map i podziękowaniem dla wszystkich, którzy przyczynili się do powstania jej książki, oraz wstępem.

Część I zatytułowana: „Od synagogalnej Dziewicy do Rodzicielki Boga, tj. do 431 roku" (From Temple Maiden to the Bearer of God: to the Year 431), w czterech rozdziałach omawia po kolei: wczesne niejasne wyobrażenia Maryi odczytane z Ewangelii, apokryfów i polemik wczesnego chrześcijaństwa (1); następnie, miejsce 